\title{
Mission Revision Is Critical Component Of Re-Accreditation Strategies In Schools Of Business
}

Janice Witt Smith, (E-mail: smithjw@wssu.edu), Winston-Salem State University Mak Khojasteh, Winston-Salem State University

\begin{abstract}
Many business schools in the United States and abroad market themselves as having quality programs, in part based on the level of external validation they have received through the attainment of accreditation. The most recent AACSB-IME standards seem to indicate that schools will be evaluated based on the alignment of the policies, curricula, educational programs and practices with the business school's mission. This requires that the institutions have a clear understanding of who they are, want to be become, who/what they wish to produce and who they serve. This study examines a single AACSB-IME accredited institution's efforts to revise its mission statement in an environment undergoing a major cultural shift from a baccalaureate to Master's I institution, as well as changes in key leadership.
\end{abstract}

\section{INTRODUCTION}

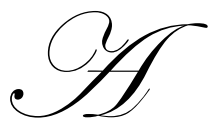

ccreditation is an external validation by agencies which evaluate the efficacy of educational programs using a variety of criteria. This process requires, in most cases, that the institution conduct an honest and detailed self-assessment, produce at least one report annually pre-accreditation, followed by at least one campus visit by the accrediting agency team. During the accreditation visit, the team will normally look for documentation to support the claims made in the reports, interview key administrators and have group meetings with faculty, and conduct spot interviews with faculty, staff, and students. The objective is that the various interviewees will have a common message and understand the school's vision, mission, and values.

The new accreditation standards focus primarily on evaluating the success of the school in accomplishing its overall individual mission. The institution's activities and requirements should both support that mission and provide value to the internal and external constituencies. Thus, a critical component of an accreditation or re-accreditation effort is for the institution to shore up its strategic planning process, to ensure that a clearly articulated mission statement drives its activities and to provide a feedback loop which leads to continuous improvement.

For the purposes of this study, strategy, which is derived from mission, is defined as "the plan of action that prescribes resource allocation and other activities for dealing with the environment, achieving a competitive advantage, and attaining organizational goals (Daft 2005:273). The mission, which is driven from the vision of the organization, is its reason for existence. Its mission statement indicates what the nature and scope of the organization is. This mission statement should differentiate this organization from other similar institutions. The mission statement of institutions of higher education should describe what the ultimate product is, identify the school's target market, and describe its strategies for accomplishing the mission (Lewis, Goodman, Fandt, \& Michlitsch, 2007:104). Vision is the organization's future aspiration and can be defined as a statement of where the organization desires to be or become in the future. It is the ultimate "grown-up" state of the organization, where it has achieved its short- and long-term goals. An organization's vision is a statement of how it wants to be seen at some point in the future. Hamel and Prahalad (1990:75) indicated that one forms a powerful vision when willing to disregard orthodoxy as one strives to understand at a deeper level customer values and the competencies needed to create and leverage solutions to meet 
those customer values. Furthermore, the organization with shared support for a common vision will be more focused in its efforts and more likely to be successful.

Consistent with Senge's fieldbook on the Fifth Discipline (1993), a continuum of five steps could be utilized to develop the vision:

1. telling - organizational members are approached with the vision and encouraged to get excited about it;

2. $\quad$ selling - motivating support for the vision;

3. $\quad$ testing - examining the vision and asking questions about it;

4. consulting - approaching organizational members (and external constituencies) and gaining their input for what should be included as part of the vision; and

5. co-creating - including the creative inputs of as many people as practical and relevant. Each step on this continuum was utilized as we engaged in our vision and mission revision process in the SBE. The length of time in each step varies depending on the knowledge and maturity of the participants involved in the process, as well as the amount of time and energy each organizational member is willing to invest in the process.

This reported study examines the strategic planning process of a Business School and describes its efforts to align its division's mission with the overall vision and mission of the entire university.

\section{Theoretical Framework}

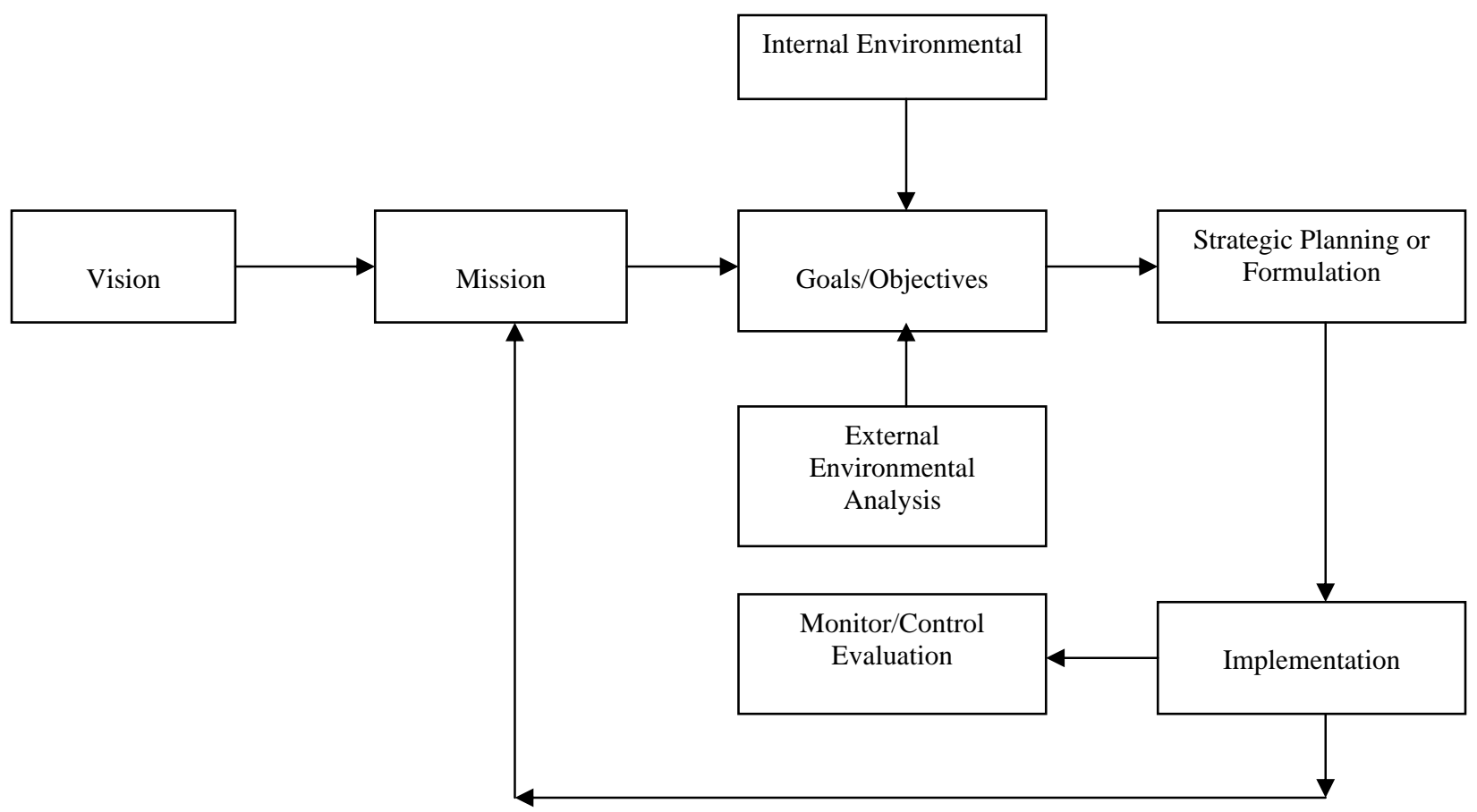

Strategic planning starts with the organization's statement of vision. Vision, as mentioned previously, is the business school's future aspiration, what it strives to become in the future. The mission statement becomes the means through which the vision becomes realizable and tangible. It identifies the institution's purpose for being and differentiates it from other organizations. The mission statement provides a sense of strate3gic direction and focuses the institution's attention on particular goals and steers it away from other goals. The mission statement helps to make the vision more specific. The goals and objectives are the vehicle through which the mission statement becomes 
more concrete. The goals may be long-term or short-term, and most successful organizations have a proper balance of both. The goals provide tangible directions for the organization's subsequent actions, and objectives are measurable, time-specific operationalizations of the goals.

Once the vision, mission, goals, and objectives have been identified, the institution must formulate the strategy by which it will pursue these ends. Re-accreditation should not be the result of this work, but it should be the natural culmination of the successful implementation and evaluation of this process. Institutions which successfully employ this strategic planning process and accomplish the mission which moves it toward its vision and where curricula, programs, activities, and actions are aligned with the vision and mission coupled with the appropriate resources and buy-in, should achieve accreditation or re-accreditation.

The institution will have its intended strategy - those things that it has defined to accomplish its mission; and will have its actual or realized strategy. Within the implementation phase of the strategic planning process, there may be a difference between what the institution intended to do and what it actually did. The intended strategies are those plans that the leaders developed; the realized strategy are the actions that actually occurred over a specific period of time. There may be internal or external environmental factors which impact the success of the organization in achieving what it expected to. The institution may have to adjust its thinking or plans as it deals with unforeseen or underestimated aspects of its internal and/or external environments. Social learning theory (Argyris, 1977) suggests that it is in this area that incremental adjustments can be made in the plan as organizational learning takes place, which will facilitate the institution's overall success.

Leadership plays a critical role in organizational learning. Their support of the experimentation process and acting upon the results of the experimentation is critical. The leaders will choose the best-winning ideas and kill the other ideas when they are not panning out and it is time for the organization to move forward. This is part of the evaluation phase of the strategic planning process. Necessary adjustments are made which requires rethinking in other parts of the process; revisions are made to the mission as needed, and the process continues.

\section{OVERALL INSTITUTIONAL CONTEXT}

The University had completed its biennial strategic planning process and had revised the vision and mission statements. As part of the strategic planning process, each School was asked to re-examine its mission statement and its alignment with the University's revised statement. The University also included a section on what students graduating from the institution should know, should have in terms of attributes, or be able do. This process and format was to provide the framework for School mission statement revisions.

The School of Business and Economics (SBE) had engaged in the strategic planning process 2 years prior to the revision of the mission statement. This process had resulted in a detailed strategic plan in relation to vision, mission, goals and objectives; however, the action items were not fully articulated or implemented. During the ensuing period, the SBE leadership went through a transition, the University upgraded its admission standards, and the university system launched a shared governance initiative. Additionally, there was a strong push to move the institution from baccalaureate to Master's 1 status (necessitating a change in faculty selection and tenure standards). All of these initiatives were deemed high priority and mission critical.

\section{ORGANIZATIONAL CONTEXT}

The institution is a southeastern liberal arts university with an enrollment of approximately 6,000 students. This institution was originally designated a historically Black College or University (HBCU) campus under an act of U.S. Congress and has a long history within the African-American community. There are a number of deeply embedded cultural elements which link the student population to the institution's African-American heritage.

The SBE is one of four academic units on campus with 30 full-time tenure-track faculty with terminal degrees and student enrollment of 700, second highest to the School of Health Sciences. This unit had been positioned to be one of the key drivers on campus as the university moved to Master's 1 status and launched additional graduate 
programs and undergraduate majors. The faculty is diverse with respect to national origin and race. The student population of SBE is approximately $87 \%$ African-American, with $80 \%$ of the faculty non-African-American.

\section{PROPOSED STRATEGIC DEVELOPMENT PLAN PROCESS}

One of the first charges of the strategic planning committee was to develop a process to guide the development of the strategic plan. The following steps are part of that process:

Step 1: Meet with various constituencies, such as faculty and administrative staff) concerning organizational values (Completed through two faculty/staff retreats. Review of this step reflected the need to include administrative support staff, students, and advisory councils and broader constituencies for agreement. Carried out by Dean with Business Advisory Board)

Step 2: Develop values statements which will assist in vision and mission revision.

Step 3: Establish Strategic Planning Committee - SPC - with external member from Chancellor's Administrative Staff. Request faculty input on revising vision and mission statements.

Step 4: Strategic Planning Committee - Develop proposed vision and mission statements.

Step 5: Circulate proposed vision and mission statements to SBE faculty, staff, students and advisory councils and gain further input. Develop timeline for completion of strategic plan.

Step 6: Refine proposed vision and mission statements based on input. Ask question: "What do we want students to know or be able to do as a result of their matriculation at Institution XYZ?" At the same time, the SBE Curriculum Committee is to examine the current learning objectives and ensure that each major has learning objectives for the major and the core courses in the SBE curriculum. Circulate to various constituencies.

Step 7: Develop focal areas for strategic plan development based on institutional strategic plan, but focusing on uniqueness of SBE.

Step 8: Develop objectives, goals, and strategies - break down by focal areas

Step 9: Develop curricula which meet objectives, goals and strategies

Step 10: Develop timeline for curriculum revision.

Step 11: Re-evaluate goals, objectives and strategies annually and construct additional ones for the next planning horizon (1-2 years out)

Step 12: Provide feedback to primary constituencies at every step of process where their input was obtained.

These steps were followed over a one-year period, and a strategic plan was formulated but not fully implemented. The university's strategic plan is formulated for a two-year period and is subsequently revised. After the "close" of the university's strategic plan for that biennium, their mission, goals and objectives were revised. The process within the School continued with another look at the school's mission statement and alignment with the University's mission, goals and objectives, and a charge to ensure that the entire process was followed and an action plan implemented. 


\section{MISSION STATEMENT REVISION PROCESS}

\section{Pre-Work}

The SBE Dean asked the strategic planning committee chair to lead the mission revision process. The chair was given the opportunity to constitute the mission revision team, which included faculty, staff, undergraduate students, and graduate students. The committee chair invited several faculty colleagues who had been part of the original strategic planning process and two who were new to the institution and had no history with the process, to participate. A new administrative support staff member was invited to participate. A representative was selected from the Student Advisory Council; and the MBA Director was asked to recommend a graduate student, who then agreed to serve. The SBE Business Advisory Council, consisting of local and regional corporate members, as well as members representing the University's executive office, also provided their input.

The existing mission statement was distributed to all SBE constituencies. At every step of the process, each constituency was asked to provide their input, and their feedback was incorporated into further deliberations. The meetings of the mission revision committee were published and open for other faculty, staff, students, and the advisory committees to participate. The chair provided an update after each meeting, with the draft revision and recommendations made by the different groups

\section{Identification Of Student Characteristics As Final "Product Of SBE Education.”}

The mission revision committee recommended (and the faculty and staff agreed) that part of the mission revision process should include an identification of student competencies as a result of our "treatment" of SBE education: "What should students know or be able to do as a result of having been educated in the SBE?"

A brief survey was developed and administered. The first iteration of the survey consisted of two openended questions that both graduate and undergraduate business students in selected business classes were asked to answer:

1. What do you want to know, be able to do, and understand as a result of your education through the School of Business and Economics at XYZ University?

2. They were given an opportunity to identify areas critical to their success through a modified Likert 5-point scale [where 1 is not at all; 2 to some extent; 3 known to a moderate extent, 4 is very important; and 5 is mission critical] - "To what extent do you believe that knowledge of the following areas (technology, knowledge of the global economy, knowledge about entrepreneurship, and leadership) is important to your success in the business world?"

They were then asked if there were other areas that were critical to their success. If they answered yes, they responded to an open-ended question that asked, "Please identify any other areas critical for your success and give a brief statement of why you believe they are important." These results were listed and the number of responses indicated for each of the questions and were provided to the various constituencies.

The committee conducted a search of the leadership literature and analyzed anecdotal, archival, and website information to include what MBA and other graduate programs expected from prospective students. The Wall Street Journal (2005) had published an article during this period that indicated what the top MBA schools were looking for in their students. This information was included in the pool of potential characteristics/attributes that graduates of our program should possess.

The committee chair, with a background in human resource management and leadership, developed a more detailed survey in which the critical success factors for business school graduates, gathered from the input from various constituencies and the literature review, were listed and defined. The definitions were critical to anchor the terms so that there would be less ambiguity about what the attributes meant for the purposes of our study. 
Table 1 - Student Expectations of SBE “Treatment” (55 students)

- $\quad$ Accounting acumen

- $\quad$ Analytical Skills

- $\quad$ Appropriate business behavior (5)

o Business Etiquette

- $\quad$ Career preparation (4)

- $\quad$ Communication (19)

$0 \quad$ Oral and written presentations (2)

- $\quad$ Coops

- $\quad$ Customer service

- $\quad$ Dealing with personal finances (3)

- $\quad$ Dependability

o Dining Etiquette

- $\quad$ Expertise in Excel

- $\quad$ Financial acumen (2)

- $\quad$ Foreign language

- $\quad$ Group work (3)

- Health care administration

- $\quad$ How to be successful in business world regardless of industry (22)

- $\quad$ How to make money (1)

- $\quad$ How to manage others (2)

- $\quad$ How to run a company (not necessarily my own) (2) o $\quad$ How business works (8)

- $\quad$ How to start, run and have a successful business of my own (12)

- How to work quickly, efficiently, and effectively

- Human resource management

- $\quad$ Integrity and honesty (2) o $\quad$ Morals and values (1)

- $\quad$ Interviewing Skills (2)

- $\quad$ Leadership (5)

- $\quad$ Marketing Skills (2)

- $\quad$ Networking (2)

- $\quad$ People skills/interpersonal skills (2)

- $\quad$ Real-world application (6)

- $\quad$ Self confidence

- $\quad$ Self development (2)

- $\quad$ Staying on cutting edge

- $\quad$ Technological skills (5)

- $\quad$ Time management 
Table 2 - Definitions of Competencies

Please complete the following survey to assist us with our continuing efforts to ensure the best educational experience for you. Each student is asked to complete this survey only one time. We would like for you to look at the following list and choose the ten most important things that you want to know, be able to do and understand as part of (a result of) your education through the School of Business and Economics at Winston-Salem State University. We have provided a brief descriptor so that we will have the same definition/concept to evaluate. Please rank them in the order of importance to you, with the most important ranked as " 1 " and the tenth most important as "10." The other items might also be important to you but do not fall in the top ten. If your most critical item is not listed, please write it in "under" and rank it as " 1. ." Thank you.

Business Acumen - A person skilled in this area understands the broader world of business, knows how businesses work, knowledgeable in current and possible future policies, practices, trends, and developments in e-commerce and information affecting business and organization. Includes understanding of the financial statements from both an end user's perspective and as a creator of those statements.

Analytical Skills - Ability to examine a situation from variety of perspectives; deals with concepts and complexity comfortably; individual is able to break down complex situations into their component parts and determine what is mission critical versus what is contextual.

Decision making - Makes good, timely decisions based on a mixture of analysis, observation, wisdom, experience and judgment. Can make decisions in a timely manner, sometimes with incomplete information and under tight deadlines and pressure.

Communication Skills - Ability to clearly exchange/transfer meaning and share information with others in oral, written, nonverbal, and electronic bases. Is able to write clearly and succinctly in a variety of communication settings and styles. Provides appropriate positive and corrective feedback to others.

Content Area knowledge - Has the functional and technical knowledge and skills to work in the area chosen as major/concentration.

Creativity/Innovation - Is good at bringing creative ideas to the table; offers unique perspectives and innovative ideas; champions new approaches and initiatives.

Ambition - Sets aggressive goals for self and others; takes decisive actions; takes initiative to go beyond what is expected;

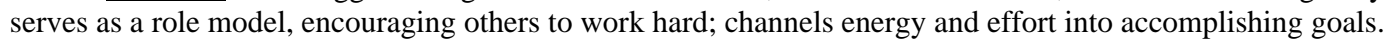

Daring/Risktaking - Challenges status-quo thinking and assumptions; identifies and supports entrepreneurial opportunities; encourages risk taking in others.

Interpersonal Skills - Relates well to others; listens carefully to input from others; extends common courtesies; demonstrates appropriate business etiquette.

Organized - Develops effective organizational structures and controls; assigns clear accountability; well organized and on time; regularly monitors progress and results; follows up on commitments; meets deadlines.

Business savvy - Understanding of political, social, cultural aspects of business environment; understanding of and ability to develop networks and strategic alliances.

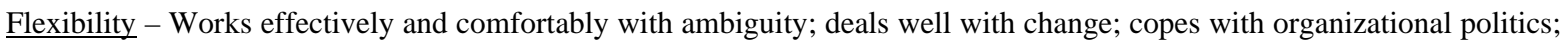
changes opinions or actions as facts and situations change.

Leadership - Is good at establishing clear directions; brings out best in people; sets stretching objectives; maintains twoway dialogue with others on work and results; persuades others to do things that benefit the overall organization.

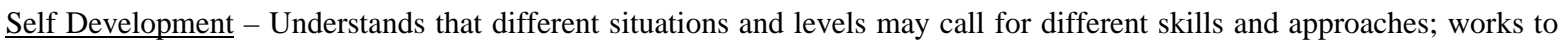
deploy strengths; works on compensating for weakness and limits; is personally committed to and actively works to continuously improve him/herself; learns from own experiences and makes needed adjustments in own behavior. 


\section{Table 2, Definitions of Competencies, Continued}

Teambuilding/teamwork - Ability to lead and to work as part of a team; lets people finish and be responsible for their own work; defines success in terms of the whole team; creates strong morale and spirit in his/her team; usually helpful to the rest of the team or other units in getting work done; will cooperate with others.

Technological Skills - Ability to utilize technology (computer, multimedia, communications, statistical, software) in a substantive and meaningful way; confidence in ability to learn new skills and to learn or adapt to new technology; not intimidated by technology; understanding and appreciation for benefit of technology

Integrity and Trust - Seen as direct, truthful individual; admits mistakes; does not misrepresent self for personal gain; keeps confidences; is widely trusted; honors commitments; demonstrates concern for others; takes responsibility; and demonstrates what they have learned so the mistake does not happen again

Professionalism - Image, attitude, appearance, language, diplomacy, tact, personal disclosure and quality consistent with an excellent-performing and well-respected individual in field or occupation.

Global Perspective - Understand linkages and interactions between domestic and international economies; has whole-world perspective of how businesses operate; understands cultural differences between countries which lead to differences in business practices.

Other: Please specify and provide a definition for each of the "other items" that you believe are critical to the success of individuals who have matriculated through the WSSU School of Business and Economics.

Those characteristics, shown in Table 2, were: Ambition, analytical skills, business acumen, business savvy, communication skills, computational and quantitative analyses, content area knowledge, corporate citizenship, creativity/innovation, daring/risk taking, decision making, emotional intelligence, ethics and values, flexibility, global perspective, integrity and trust, interpersonal skills, leadership, multicultural perspective, organized, professionalism, self-development, teambuilding/ teamwork, technological skills, and "other." In addition, from the feedback received from the students, the following characteristics were added: corporate citizenship, emotional intelligence, and business savvy.

The committee then conducted a faculty workshop where business education attributes of graduates were discussed. The faculty arrived at a consensus on what the top-priority characteristics/attributes of our students should be, as a result of the treatment called "School of Business and Economics education." The methodology for this workshop was as follows:

The committee chair facilitated the discussion; all faculty and staff were invited to participate. Seventeen faculty and administrators spent several hours together and provided tremendous input to move the process forward. Each individual was asked to complete the survey independently. They were then randomly assigned to groups who met independently and were charged with gaining their small group consensus on the top 15 attributes. The rankings from each group were displayed in the overall meeting. The facilitator asked them to look for patterns across groups and to identify the items that showed up on at least 4 of the 6 lists. This indicated group consensus among the larger group. Then the group discussed the items that were different. Two additional characteristics arose from the discussion and they were added to the questionnaire.

The questionnaire was then given to the SBE staff, student advisory board, business advisory council, students from a cross-section of classes, and the local professional chapter of the Society for Human Resource Management (SHRM) who were asked to rank the list in order of importance to their career success and to add any missing factors.

We then compiled a list indicating what the responses from the four constituencies had revealed. The analysis included three rubrics, depending on the level of agreement within the HR Professionals group - where 50\%, $67 \%$, or $75 \%$ of the groups had agreed on a characteristic. (See Table 3). 
Table 3: Student Attributes Combined Rankings for All Groups - February 9, 2006

\begin{tabular}{|c|c|c|c|c|c|c|c|c|}
\hline \multirow[t]{2}{*}{ Dimension } & \multirow[t]{2}{*}{$\begin{array}{c}\text { Faculty } \\
\text { Ranking } \\
\mathrm{N}=17, \\
\text { then } 12\end{array}$} & \multirow[t]{2}{*}{$\begin{array}{c}\text { Staff } \\
\text { Ranking } \\
\mathbf{N}=3\end{array}$} & \multirow[t]{2}{*}{$\begin{array}{c}\text { Student } \\
\text { Ranking } \\
\mathrm{N}=279\end{array}$} & \multirow[t]{2}{*}{$\begin{array}{c}\text { Graduate } \\
\text { Students } \\
\mathbf{N}=12\end{array}$} & \multirow[t]{2}{*}{$\begin{array}{l}\text { BAC } \\
N=6\end{array}$} & \multicolumn{3}{|c|}{$\begin{array}{c}\text { Employers } \\
\mathrm{N}=43\end{array}$} \\
\hline & & & & & & $50 \%$ & $67 \%$ & $75 \%$ \\
\hline Analytical Skills & 1 & 11 & 9 & 9 & 10 & 12 & 8 & 6 \\
\hline Business Acumen & 4 & 3 & 7 & 4 & 7 & 5 & & \\
\hline Communication Skills & 2 & 10 & 5 & 10 & $* * 4$ & 1 & 1 & 1 \\
\hline $\begin{array}{l}\text { Computational and Quantitative } \\
\text { Analyses }\end{array}$ & 11 & & & & & & & \\
\hline Content Area Knowledge & 3 & 2 & 3 & 7 & $* * 6$ & 7 & 4 & \\
\hline Decision making & 7 & & 19 & 13 & 8 & & & \\
\hline Ethics and Values & 5 & 6* & 10 & 5 & 1 & 2 & 2 & 2 \\
\hline Global Perspective & 9 & & 2 & 12 & & & & \\
\hline Integrity and Trust & 13 & 6* & 18 & 6 & 2 & 4 & 3 & 3 \\
\hline Interpersonal Skills & 7 & & 13 & 16 & $* * 11$ & 11 & 7 & 5 \\
\hline Leadership & 12 & 5 & 8 & 11 & $* * 6$ & & & \\
\hline Professionalism & 6 & 1 & 11 & 19 & $* * 3$ & & & \\
\hline Teambuilding/Teamwork & 8 & 9 & 20 & 14 & $* * 4$ & & 9 & 7 \\
\hline Technological Skills & 10 & 8 & 12 & 1 & & 8 & & \\
\hline Ambition & & 6 & 1 & 2 & $* * 3$ & 3 & & \\
\hline Business Savvy & & 4 & 15 & 5 & & 6 & & \\
\hline Corporate Citizenship & & & & & & & & \\
\hline Creativity/Innovation & & 3 & 4 & 15 & $* * 5$ & & 10 & 8 \\
\hline Daring/Risktaking & & & 17 & 8 & 9 & & & \\
\hline Emotional Intelligence & & & & & & & & \\
\hline Flexibility & & & 16 & 18 & $* * 11$ & & & \\
\hline Multicultural Perspective & & 11 & & & & & & \\
\hline Organized & & 7 & 6 & 17 & $* * 5$ & 9 & 5 & 4 \\
\hline Self Development & & & 14 & 3 & $* * 5$ & 10 & 6 & \\
\hline Other & & & & & & & & \\
\hline $\begin{array}{l}\text { Preparing Students for } \\
\text { Handling Interviews - Prof17 }\end{array}$ & \multirow{2}{*}{\multicolumn{8}{|c|}{$\begin{array}{l}\text { ** Number of ties with BAC } \\
\text { Employer Ratings - Used } 5 \text { rules - } 50 \% \text { or more had to rank dimension; rankings greater than } \\
15 \text { were not included; looked at attributes where } 50 \% \text { ranked in top } 15 ; 67 \% \text { ranked in top } 15 \\
\text { and } 75 \% \text { ranked in top } 15 .\end{array}$}} \\
\hline $\begin{array}{l}\text { Computational and Quantitative } \\
\text { Analyses left off in error from } \\
\text { professional survey. None } \\
\text { entered as "Other.” In debrief, } \\
\text { they felt analytical skills would } \\
\text { encompass; use of computers } \\
\text { reduces need. }\end{array}$ & & & & & & & & \\
\hline
\end{tabular}

The SBE Dean was asked to have an additional meeting, so that the faculty could determine which rubric to use to merge the data and come up with a final, combined list of characteristics that appropriately weighed the responses. This final list would be used to complete the vision and mission statements and to assist with curriculum review. The vision was slightly tweaked, and the committee revised the existing mission statement and submitted it to the same constituencies for their input. There were seven iterations to the review-revision process, where input was gathered and recommended revisions were made. The top leadership from the University participated in a meeting with SBE faculty and administrators to provide their viewpoint on the SBE mission revision process and the proposed revised mission statement draft. Additional input was gathered and another version of the mission statement draft was created and circulated. 


\section{SAMPLE}

There were responses from 17 out of 27 faculty (including administrators), 3 out of 5 staff, 279 undergraduate students (including the student advisory council) out of 650 students; 12 graduate students out of 30; 6 out of the 9 members of the Business Advisory Council, and 43 out of 60 employers who responded to this survey. The total population was 781 individuals, with an overall response rate of 360 out of 781 (46.09475) or 46.1\%. The response rate for the survey was $63 \%$ for faculty and administrators; $60 \%$ for staff; and $39.7 \%$ for students.

\section{RESULTS}

The top fifteen characteristics (including ties), based on 5 or more constituencies agreeing that the characteristic was in the top 15, were: analytical skills, business acumen, communication skills, content area knowledge, ethics and values, integrity and trust, interpersonal skills, leadership, professionalism, team building/teamwork, technological skills, ambition, business savvy, creativity/innovation, organized, and selfdevelopment.

Table 4 - Student Characteristics As Result of Education

\begin{tabular}{|l|l|l|}
\hline \multicolumn{1}{|c|}{$\mathbf{5 0 \%}$ Rule } & \multicolumn{1}{c|}{$\mathbf{2 / 3 s}$ rule } & \multicolumn{1}{c|}{$\mathbf{3 / 4 s}$ rule } \\
\hline Ambition & Analytical Skills & Analytical Skills \\
\hline Analytical Skills & Communication Skills & Communication Skills \\
\hline Business Acumen & Content Area Knowledge & Creativity and Innovation \\
\hline Business Savvy & Creativity and Innovation & Ethics and Values \\
\hline Communication Skills & Ethics and Values & Integrity and Trust \\
\hline Content Area Knowledge & Integrity and Trust & Interpersonal Skills \\
\hline Creativity and Innovation & Interpersonal Skills & Organized \\
\hline Ethics and Values & Organized & Teambuilding/Teamwork \\
\hline Integrity and Trust & Self Development & \\
\hline Interpersonal Skills & Teambuilding/Teamwork & \\
\hline Organized & & \\
\hline Self Development & & \\
\hline Teambuilding/Teamwork & & \\
\hline Technological Skills & & \\
\hline
\end{tabular}

\section{IMPACT OF MISSION REVISION PROCESS ON RE-ACCREDITATION STRATEGIES}

The revision of the mission statement was approved by the faculty in April 2006. This process required 5 months of intense work and a number of meetings and animated discussions to arrive at this point. The organizational Strengths, Weaknesses, Opportunities and Threats (SWOT) preliminary report revision was submitted by another ad hoc committee, and approval of their results by the faculty is pending. A number of new programs were approved and major curricula revisions were made prior to the approval of the mission statement revision. As this work proceeded under the old vision and mission statements, a detailed review must be completed to ensure that these initiatives align with the revisions.

New faculty members were hired in Fall 2006 and the new dean took the position July 2006. The vision and mission statements were again reviewed; focus groups were held; additional input was gathered, and the mission statement was revised and approved. The internal groups were again asked to review the revised mission statement and to examine the alignment of the academic programs (majors, minors, and certificate programs in the School of Business), learning objectives for courses in the SBE core curriculum, SBE programs, student organizations and initiatives with the mission and vision statements. Goals and objectives for each academic major/discipline were examined and revised as needed. The next step is our process is to identify and implement the action steps and to establish a timetable with feedback and re-evaluation. 
Faculty were asked to create assessments to measure the extent to which individual academic courses met the revised learning objectives; and the need for additional or modified courses and programs were discussed. Several school-wide initiatives were launched which further support the institution’s revised mission.

As critical piece of the mission revision process is ensuring that resources are available to make the changes needed to facilitate alignment between practice and purpose (the mission). Faculty were provided with additional opportunities for career development to regain of solidify Academically Qualified (AQ)/Professionally Qualified (PQ) status; additional travel funds were provided for teaching and discipline-based conferences and grant-writing.

Job descriptions for staff were updated to reflect their positions and competencies within the new culture and climate. Additional lines for faculty hire were generated, and strategic opportunities identified to facilitate the attainment of the vision through the revised mission and its associated goals and objectives.

According to the revised standards for AACSB-IME, the schools of business will be evaluated based on the strategic alignment of vision, mission, and programs.****

The process outlined in this research study demonstrates the challenges and opportunities associated with a deliberate and purposeful, albeit time and labor-intensive, mission revision process. The work done in creating buy-in and ensuring that the internal and external constituencies have input should result in human and financial resources working together to make a value-added contribution to the students and business community. A natural outcome of this accomplishment should be re-accreditation.

\section{KEY LEARNINGS}

It is critical that the leadership of the School of Business and Economics (or of any unit or division) understands and has a commitment to a high-quality mission revision process which includes the input of all key constituents. One individual's perspective cannot drive the mission revision process. Once information has been gathered, some key decisions have to be made even if all information is not known. The mission revision process must be given priority over other activities, and development of strategic initiatives without a completed mission revision should be suspended.

Students can contribute significantly to the process and their input should be included, as appropriate, at every step during the revision. Current and former students were included in this effort, and they provided a perspective that could easily have been overlooked. Partnerships with the business community (which in this case was primarily through Human Resource community) are also invaluable. The students are the institution's internal customer and end product, and the business community, our external customer.

\section{REFERENCES}

1. AACSB-IME Accreditation Guidelines on AACSB website.

2. Argyris, C. (1977). Double Loop Learning in Organizations, Harvard Business Review (September-October 1977), 115-125.

3. Daft, R. L. (2005). Management, $7^{\text {th }}$ Edition, South-Western Publishing Company, Mason, OH.

4. Hamel, G. and Prahalad, C.K. (1990) Competing for the Future.

5. Lewis, Goodman, Fandt, \& Michlitsch (2007). Management: Challenges for Tomorrow's Leaders, $5^{\text {th }}$ edition, Publishing Company

6. $\quad$ Livers \& Cavers (2003). Leading in Black and White. San Francisco: Jossey Bass.

7. Prahalad, C.K. \& Hamel, G. (1990). The core competence of the corporation. Harvard Business Review, May-June, 79-91.

8. $\quad$ WSSU Strategic Plan (2003-2005).

9. Wall Street Journal (April 14, 2004). What Employers want from MBA Graduates. 


\section{NOTES}

